\title{
THE THERMAL-HYDRAULIC CALCULATION IN A FUEL CARTRIDGE WHEN THE SYMMETRY OF FUEL RODS PACKING IS BROKEN
}

\author{
T. I. Sheyko ${ }^{1 *}$ K. V. Maksimenko-Sheyko ${ }^{1,2}$, R. A. Uvarov ${ }^{1}$, \\ M. A. Khazhmuradov ${ }^{3}$ \\ ${ }^{1}$ A.N. Podgorny's Institute for Mechanical Engineering Problems of NAS of Ukraine, Kharkiv, Ukraine; \\ ${ }^{2}$ V. N. Karazin Kharkiv National University, Kharkiv, Ukraine; \\ ${ }^{3}$ National Science Center "Kharkiv Institute of Physics and Technology" Kharkiv, Ukraine
}

(Received June 6, 2018)

\begin{abstract}
In the work, the problem of convective heat transfer in the fuel cartridge with fuel rods, including the case of broken symmetry in the packing of rods, is solved with new design tools of the R-functions method and the program complex POLYE. The developed design tools for constructing the equations of the boundaries of domains with translational and cyclic types of symmetry made it possible to significantly reduce the quantity of operations with a subsequent automation of this process, and, consequently, to reduce the time for solving problems. Problems are solved by a variational-structural method. The paper considers the influence of only one rod that breaks the symmetry of the packing, when it is located either in the central or in the peripheral zone of the cartridge, both with keeping the whole bundle parallel and with the rod's curvature. In the presence of several "non-standard" rods, it is also important to calculate the temperature field for the cartridge as a whole. Working with the mathematical model of the process and the computational experiment make it possible to study the properties and behavior of the process in various situations without serious consequences, relatively quickly and without significant expenditure.
\end{abstract}

PACS: 28.41.Bm,44.05.+e,47.11.-j

\section{INTRODUCTION}

Reactor fuel assemblies used in the power engineering are bundles of fuel rods. Processes of hydrodynamics and heat transfer in such systems are quite complex, but their precise description is necessary in order to achieve the optimal design characteristics at nominal operating modes as well as to analyze the reliability in deviations from nominal modes and in emergency states. For example, an accurate calculation of the temperature conditions of fuel elements in fast reactors makes it possible to refine the estimated sizes, swelling and bending of elements, etc., which determines the operability of the reactor core and the allowable level of fuel burn-up. Increasing the requirements for the thermal-hydraulic calculation of fuel cartridges has led to the development of new methods for the theoretical investigation of processes in bundles of fuel rods. Currently developed methods and programs $[1,2,3]$ differ in terms of initial solvable equations and methods for their solution, the consideration of various factors, the relations for initial constants, and, accordingly, on the calculation accuracy and classes of problems to be solved. A common feature for all techniques is a closed relationship between the velocity and temperature fields.
It is impossible to calculate the heat transfer reliably without knowing the velocity field. In [3], the conjugate heat transfer problem under the rod flow of the heat transfer agent in the lattices of fuel elements was reduced to a solution for one translational element based on the symmetry of the system. However, an analysis of the nature of the velocity and temperature distribution performed in $[7,8,9]$ allows us to conclude that the consideration of the velocity field for a cell, in the case of its remoteness from the boundary, is expedient. The temperature field in this case will be very far from reality, as evidenced by the results obtained for the cartridge as a whole. In $[4,5,6]$, the foundations of new constructive tools of the theory of R-functions for the analytical description of geometric objects with various types of symmetry, including translational and cyclic, were laid. In $[7,8]$, equations of cartridges with 96 or more fuel elements have been constructed, and investigations of hydrodynamic and temperature fields by the Rfunction method have been started. The paper [9] is devoted to the mathematical modeling of convective heat transfer in an octagonal fuel cartridge with 37 fuel elements as well as to the investigation of the packing type (checkerboard, corridor and cyclic) influence on the form of the resulting fields.

\footnotetext{
*Corresponding author E-mail address: sheyko@ipmach.kharkov.ua
} 
The aim of this work is the appliance of new constructive tools of the R-functions method and the POLYE software package for thermal-hydraulic calculation of fuel rod cartridges, including the case of broken symmetry in the rods packing.

\section{MAIN PART}

The basic system of equations describing the process of heat transfer in a viscous fluid flow with variable physical properties is very complex, and its general solution is associated with the difficulties caused by the nonlinearity of the equations of motion and energy in the presence of convective terms, the dependence of the physical properties of the liquid on temperature. Due to the dependence of the dynamic coefficient of viscosity $\mu$ and the density of the fluid $\rho$ on the temperature $T$ velocity and temperature fields are mutually related, and therefore the equations of motion and continuity can not be solved independently of the equation of energy. To simplify the problem, let us consider the case of constancy of all physical properties of the liquid and temperature, stationarity of processes, thermal stabilization in accordance with $z$ and laminar flow of the liquid. Then, from the basic system of equations

$$
\left\{\begin{array}{r}
\frac{D T}{D \tau}=\alpha \Delta T+\frac{q \nu}{\rho c_{\rho}}+\frac{\mu \Phi}{\rho c_{\rho}} \\
\frac{D \vec{V}}{D \tau}=-\frac{1}{\rho} \vec{\Delta} \rho+\nu \Delta \vec{V} \\
\operatorname{div} \vec{V}=0,
\end{array}\right.
$$

we get

$$
\left\{\begin{array}{c}
\operatorname{div}(\lambda \Delta T)=g \nu-V_{z} C_{1} \\
\Delta V_{z}=-\frac{\Delta P}{\mu l}=-C
\end{array}\right.
$$

where:

$\frac{D}{D \tau}=\frac{\partial}{\partial \tau}+(\vec{V} \cdot \vec{\Delta})-$ the substantial (or total) derivative,

$\mu \Phi$ - dissipative function,

$\alpha=\frac{\lambda}{\rho c_{\rho}}-$ coefficient of thermal diffusivity,

$c_{\rho}$ - heat capacity of medium,

$q \nu$ - capacity of internal heat sources,

$\Delta P$ - constant pressure drop along the tube on an arbitrarily selected portion of the length $l$.

Thus, the mathematical model of heat transfer in the laminar flow of a liquid along a cartridge with fuel elements reduces to a system of equations

$$
\left\{\begin{array}{l}
\Delta V_{z}=-C \text { in } \Omega_{b} \bigcap \overline{\Omega_{t \nu}} \\
-\operatorname{div}\left(\lambda_{i} \Delta T_{i}\right)=F_{i} \text { in } \Omega_{b},
\end{array}\right.
$$

where

$$
\left\{\begin{array}{r}
F_{1}=-V_{z} \quad \text { in } \quad \Omega_{b} \bigcap \overline{\Omega_{t \nu}} \\
F_{2}=q_{V} \text { in } \Omega_{t \nu}
\end{array}\right.
$$

with boundary conditions of the form

$$
\begin{array}{r}
\left.V_{z}\right|_{\partial \Omega_{b}} \cap \overline{\partial \Omega_{t \nu}}=0, \\
\frac{\partial T}{\partial n}+\left.h T\right|_{\Omega_{b}}=0, \\
\left.T_{1}\right|_{\partial \Omega_{t \nu}}=\left.T_{2}\right|_{\partial \Omega_{t \nu}}, \\
\left.\lambda_{1} \frac{\partial T_{1}}{\partial n_{1}}\right|_{\partial \Omega_{t \nu}}=\left.\lambda_{2} \frac{\partial T_{2}}{\partial n_{2}}\right|_{\partial \Omega_{t \nu}}
\end{array}
$$

Consider a typical structural diagram of the reactor, which core is assembled from a large number of fuel cartridges $[2,7]$. These cartridges are hexagonal casings, where fuel elements are placed.

To construct the equations corresponding to geometric objects with translation symmetry along a straight line, we use the following theorem $[5,6]$.

Theorem 1. Let the translation domain $\sum_{0}=\left[\sigma_{0}(x, y, z) \geq 0\right]$ be symmetrical about the axis $O y$ and can be enclosed in a vertical band $-a<x<a$, and the domains $\sum_{i}=\left[\sigma_{0}(x-h i, y, z) \geq 0\right]$ be obtained as a transformation result of transferring the domain $\sum_{0}$ along the abscissa axis by multiples of $h>2 a$. Then the equation of the boundary $\partial \Omega$ of the domain

$$
\Omega=\bigcup_{i \in Z} \sum_{i}
$$

has the form where

$$
\omega(x, y, z) \equiv \sigma_{0}(\mu(x, h), y, z)=0,
$$

$$
\mu(x, h)=\frac{4 h}{\pi^{2}} \sum_{i=1}^{\infty} \frac{(-1)^{i+1}}{(2 i-1)^{2}} \sin \frac{(2 i-1) x \pi}{h} .
$$

To construct the equations corresponding to geometric objects with point symmetry of cyclic type, we use the following theorem $[5,6]$.

Theorem 2. Let the translational domain $\sum_{0}=\left[\sigma_{0}(x, y, z) \geq 0\right]$ be symmetrical about the abscissa axis, and the domain $\sum_{1}=\left[\sigma_{0}\left(x-r_{0}, y, z\right) \geq 0\right]$ can be located within the sector

$$
-\alpha \leq 0 \leq \alpha, \quad 0<\alpha<\frac{\pi}{n},
$$

domains

$\sum_{k}=\left[\sigma_{0}\left(r \cos \left(\theta-\frac{2 \pi k}{n}\right)-r_{0}, r \sin \left(\theta-\frac{2 \pi k}{n}\right), z\right) \geq 0\right]$ be obtained as a result of turning the domain

$$
\sum_{1}=\left[\sigma_{0}\left(x-r_{0}, y, z\right) \geq 0\right]
$$

in the plane $x O y$ around the origin to angles $\frac{2 \pi k}{n}$.

Then the equation of the boundary $\sigma \Omega$ of the domain

$$
\Omega=\bigcup_{k=0}^{n-1} \sum_{k}
$$

has the form

$$
r=\sqrt{x^{2}+y^{2}}, \theta=\arctan \frac{y}{x},
$$$$
\text { where }
$$$$
\omega(x, y)=\sigma_{0}\left(r \cos \mu(\theta, n)-r_{0}, r \sin \mu(\theta, n), z\right)=0,
$$ 


$$
\mu(n \theta)=\frac{8}{n \pi} \sum_{k}(-1)^{k+1} \frac{\sin [(2 k-1)(n \theta / 2)]}{(2 k-1)^{2}} .
$$

Construct the equation of fuel cartridge with 169 fuel elements and extended triangular packing, which is called checkerboard sometimes. Note that when applying conventional methods used in the theory of R-functions [4], we obtain 171 R-operations in the general equation of the fuel cartridge as a result. The cumbersome formula will not only lead to an increase in the counting time, but also, possibly, to some symmetry breaking due to the non-associative nature of R-operations. Therefore, we use Theorem 2 to construct the equation of hexagonal casing.

Consider the equation of the line

$\sigma \equiv R_{\nu}-x \geq 0$

and a periodic function

$$
\mu_{\nu}=\frac{4}{3 \pi} \sum_{k}(-1)^{k+1} \frac{\sin [(2 k-1) 3 \theta]}{(2 k-1)^{2}} .
$$

As a result, we get

$\omega_{b} \equiv R_{\nu}-R \cos \mu_{\nu} \geq 0$,

where

$$
r=\sqrt{x^{2}+y^{2}}, \theta=\arctan (y / x) .
$$

To construct a triangular packing of fuel elements, we use Theorem 1. Define translational equations of fuel elements

$$
\begin{aligned}
& f_{1}=R^{2}-\mu_{x}^{2}-\mu_{y}^{2} \geq 0, \\
& f_{2}=R^{2}-\mu_{x 1}^{2}-\mu_{y 1}^{2} \geq 0,
\end{aligned}
$$
where

$$
\begin{array}{r}
\mu_{x}=\frac{4 h_{x}}{\pi^{2}} \sum_{k}(-1)^{k+1} \frac{\sin \left[(2 k-1) \frac{\pi x}{h_{x}}\right]}{(2 k-1)^{2}}, \\
\mu_{y}=\frac{4 h_{y}}{\pi^{2}} \sum_{k}(-1)^{k+1} \frac{\sin \left[(2 k-1) \frac{\pi x}{h_{y}}\right]}{(2 k-1)^{2}}, \\
\mu_{x 1}=\frac{4 h_{x}}{\pi^{2}} \sum_{k}(-1)^{k+1} \frac{\sin \left[(2 k-1) \pi\left(x-h_{x} / 2\right)\right]}{(2 k-1)^{2}}, \\
\mu_{y 1}=\frac{4 h_{y}}{\pi^{2}} \sum_{k}(-1)^{k+1} \frac{\sin \left[(2 k-1) \pi\left(y-h_{y} / 2\right)\right]}{(2 k-1)^{2}} .
\end{array}
$$

Then the equation of fuel cartridge takes the form

$$
\begin{gathered}
\omega \equiv \omega_{b} \bigwedge_{0} \overline{\omega_{t \nu}} \geq 0 \\
\omega_{t \nu} \equiv\left(f_{1} \bigvee_{0} f_{2}\right) \geq 0 .
\end{gathered}
$$

The function $\omega(x, y)$ is constructed with the following values of the letter parameters: $R=1.542$, $h_{x}=11.9248, h_{y}=6.939, n_{0}=6, r_{k}=46$. It should be noted that R-operations were used only twice in the equation of fuel cartridge by the proposed technique.
The construction of displaced fuel elements was carried out as follows.

For displacement in the central zone

$$
\omega_{t \nu} \equiv\left(\left(f_{1} \bigvee_{0} f_{2}\right) \bigwedge_{0} \overline{f_{\rho}}\right) \bigvee_{0} f_{s} \geq 0,
$$

where

$$
\begin{array}{r}
f_{s}=\frac{R^{2}-\left(x-\frac{h_{x}}{3}\right)^{2}-y^{2}}{2 R} \geq 0, \\
f_{\rho}=\frac{(R+\delta)^{2}-\left(x-h_{x}\right)^{2}-y^{2}}{2 R} \geq 0 .
\end{array}
$$

For displacement in the far zone

$$
\omega_{t \nu} \equiv\left(\left(f_{1} \bigvee_{0} f_{2}\right) \bigwedge_{0} \overline{f_{\rho d}}\right) \bigvee_{0} f_{s d} \geq 0,
$$

where

$$
\begin{gathered}
f_{s d}=\frac{R^{2}-\left(x-\left(3 h_{x}-\frac{h_{x}}{3}\right)\right)^{2}-y^{2}}{2 R} \geq 0, \\
f_{\rho d}=\frac{(R+\delta)^{2}-\left(x-3 h_{x}\right)^{2}-y^{2}}{2 R} \geq 0 .
\end{gathered}
$$

Note that structurally the formula (5) and (6) are similar.

For the solution of (3), (4) we used the Rfunctions method in combination with the Ritz variational method. The structure of the solution of the laminar flow problem for longitudinal flow past fuel rods has the form

$$
V_{z}=\omega \rho_{1},
$$

where

$$
\omega(x, y) \equiv \omega_{b} \bigwedge_{0} \overline{\omega_{t \nu}} \geq 0
$$

- equation of the boundary of the cross section of the fuel cartridge,

$$
\rho_{1}=\sum_{i=1}^{N} c_{i k} \varphi_{i k}(x, y)
$$

- undefined component sought, minimizing the functional

$$
I=\int_{\Omega}\left(\left(\nabla V_{z}\right)^{2}-2 C V_{z}\right) d \Omega .
$$

Note that the solution $V_{z}$ is obtained analytically and used without any further processing (approximation, interpolation), substituting in the righthand side of the equation of thermal conductivity. The structure of the solution of the problem of determining the temperature field was used as exactly satisfying the boundary conditions on $\partial \Omega_{b}$ $u=\rho_{2}+\omega_{b}\left(-D_{1} \rho_{2}+h \rho_{2}\right)$, and as in the form $T=\rho_{2}$, where, as before,

$$
\rho_{2}=\sum_{i=1}^{N} d_{i k} \varphi_{i k}(x, y) .
$$


Here it should be noted that the boundary conditions

$$
\frac{\partial T}{\partial n}+\left.h T\right|_{\omega_{b}}=0
$$

and

$$
\left.\lambda_{1} \frac{\partial T_{1}}{\partial n_{1}}\right|_{\partial \Omega_{t \nu}}=\left.\lambda_{2} \frac{\partial T_{2}}{\partial n_{2}}\right|_{\partial \Omega_{t \nu}}
$$

are natural and follow from the Ritz functional

$$
I=\int_{\Omega}\left(\lambda(\nabla T)^{2}-2 F T\right) d \Omega+\int_{\partial \Omega_{b}} h T^{2} d \partial \Omega_{b} .
$$

In this case, the next switch has been used:

$$
\begin{aligned}
& \lambda=\lambda_{1} \frac{1+\operatorname{sign} \omega}{2}+\lambda_{2} \frac{1-\operatorname{sign} \omega}{2}, \\
& F=q \nu \frac{1-\operatorname{sign} \omega}{2}-V_{z} \frac{1+\operatorname{sign} \omega}{2} .
\end{aligned}
$$
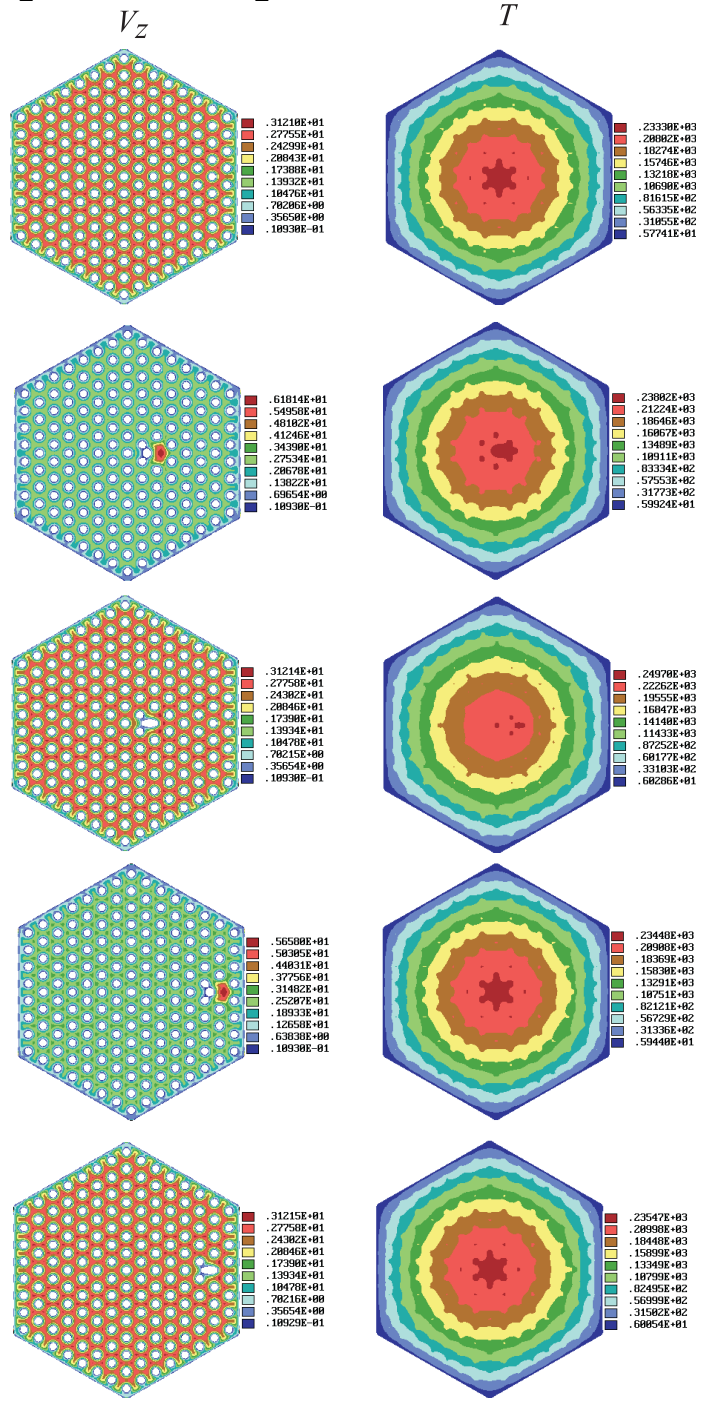
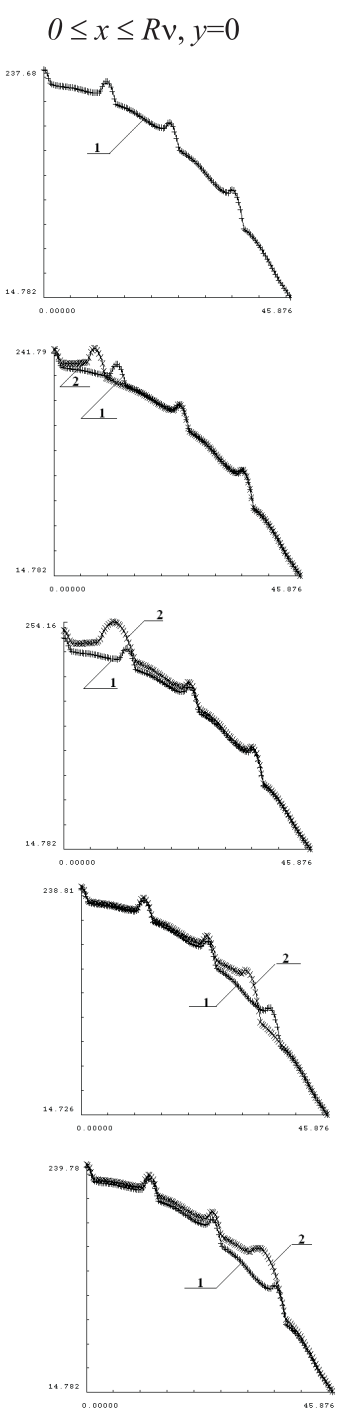

Pictures of the distribution of the velocity field and the temperature field, including a broken symmetry of the rods packing, and a comparative analysis of the graphs in the cross section $0 \leq x \leq R_{\nu}, y=0$ 


\section{CONCLUSIONS}

It is shown that the R-functions method is effective for solving the problems of the physical field calculation in complex shape structural elements of nuclear power plants. The developed design tools for constructing the equations of domain boundaries with translational and cyclic symmetry types allowed to significantly reduce the number of operations with subsequent automation of the process, and, hence, to reduce the time for solving the problems. In this paper, only one rod that breaks the symmetry of the packing is considered. Multiple "custom" cores will lead to more significant temperature field calculations for the cartridge as a whole. Mathematical modeling and the computer experiment associated with it are indispensable in those cases when the natural experiment is impossible or difficult for one reason or another. In addition, working with the mathematical model of the process and the computational experiment make it possible to study the properties and behavior of the process in various situations with no pain, relatively quickly and without significant expenditure. At the same time, computational experiments with object models allow us to study them thoroughly and deeply, relying on modern numerical methods. The reliability of the analytical identification of cartridges is confirmed by their visualization. The reliability of calculation methods, results and conclusions is confirmed by an analysis of the numerical convergence of solutions and by a calculation of the residual.

\section{References}

1. A.G. Tarapon. The cause of the accident at the Chernobyl nuclear power plant. Modeling of processes of reactor destruction and thermal conductivity in the Shelter object. Kiev: G.E.Pukhov Institute of Modelling Problem in Power Engineering of the NAS of Ukraine, 2006, p.183 (in Russian).
2. B.S. Petukhov, L.G. Genin, S.A. Kovalev. Heat ex-change in nuclear power plants. Moscow: "Atomizdat", 1974, p.367 (in Russian).

3. A.P. Slesarenko, D.A. Kotulsky. Regionalanalytical and variational methods in solving the conjugative problems of convective heat transfer // Heat mass exchange MIF-2000, Proceedings of IV Minsk international forum (Belarus, Minsk, May 2000). Minsk: IHME AS of Belarus, 2000, v.3, p.135-142 (in Russian).

4. V.L. Rvachev. The theory of R-functions and its several applications. Kiev: "Naukova dumka", 1982, p.552 (in Russian).

5. K.V.Maksimenko-Sheyko. The R-functions in ma-thematical modelling of geometrical objects and physi-cal phields. Kharkiv: "IPMach NASU", 2009, p.306 (in Russian).

6. K.V. Maksimenko-Sheyko, T.I.Sheyko. Rfunctions in mathematical modeling of geometric objects with symmetry // Cybernetics and Systems Analysis. 2008, N6, p.75-83 (in Russian).

7. K.V. Maksimenko-Sheyko,

R.A. Uvarov, T.I. Sheyko. The R-functions method in mathematical modeling of convective heat transfer in fuel cartridge with fuel rods // Problems of Atomic Science and Technology. Series "Nuclear Physics Investigations". 2013, N3(85), p.205-209.

8. K.V.Maksymenko-Sheyko, A.V. Tolok , T.I. Sheyko. Connected problem of the convective heat transfer in the fuel cartridge of the power rods // Informational Technologies. 2013, N11, p.32-36 (in Russian).

9. R.A. Kolyada, K.V. Maksymenko-Sheyko, T.I. Sheyko. The R-functions method in mathematical modeling of convective heat transfer in the octahedral fuel cartridge with 37 fuel rods // Mathematical methods and physical-mechanical fields. 2016, v.59, N4, p.128-134 (in Russian).

\title{
ТЕПЛОГИДРАВЛИЧЕСКИЙ РАСЧЕТ КАССЕТ ТВЭЛОВ ПРИ НАРУШЕНИИ СИММЕТРИИ УПАКОВКИ СТЕРЖКНЕЙ
}

\author{
Т. И. Шейко, К. В. Максименко-Шейко, Р. А. Уваров, М. А. Хажнмурадов
}

$\mathrm{C}$ использованием новых конструктивных средств метода R-функций и программного комплекса POLYE решается сопряженная задача конвективного теплообмена в топливной кассете ТВЭЛов, в том числе в случае нарушения симметрии упаковки стержней. Разработанные конструктивные средства построения уравнений границ областей с трансляционным и циклическим типами симметрии позволили существенно уменьшить количество операций с последующей автоматизацией этого процесса, а следовательно, уменьшить и время решения задач. Задачи решаются вариационно-структурным методом. Рассмотрено влияние лишь одного стержня, нарушающего симметрию упаковки и расположенного сначала в центральной, а затем в периферийной зоне кассеты, как при сохранении параллельности всего пучка, так и в случае искривления стержня. При наличии нескольких "нестандартных"стержней существенным также является расчет температурного поля для кассеты в целом. Работа с математической 
моделью процесса и вычислительный эксперимент дают возможность безболезненно, относительно быстро и без существенных затрат исследовать свойства и поведение процесса в различных ситуациях.

\title{
ТЕПЛОГІДРАВЛІЧНИЙ РОЗРАХУНОК КАСЕТ ТВЕЛІВ ПРИ ПОРУШЕННІ СИМЕТРІЇ УПАКОВКИ СТРИЖНІВ
}

\author{
Т. І. Шейко, К. В. Максименко-Шейко, Р. О. Уваров, М. А. Хажсмурадов
}

3 використанням нових конструктивних засобів методу R-функцій і програмного комплексу POLYE вирішується сполучена задача конвективного теплообміну в паливній касеті ТВЕЛів, в тому числі у разі порушення симетрії упаковки стрижнів. Розроблені конструктивні засоби побудови рівнянь границь областей з трансляційним і циклічним типами симетрії дозволили істотно зменшити кількість операцій з подальшою автоматизацією цього процесу, а отже, зменшити і час розв'язання задач. Задачі розв'язуються варіаційно-структурним методом. Розглянуто вплив лише одного стрижня, що порушує симетрію упаковки, і розташованого спочатку в центральній, а потім в периферійній зоні касети, як при збереженні паралельності всього пучка, так і в разі викривлення стрижня. За наявності декількох "нестандартних"стрижнів істотним також є розрахунок температурного поля для касети в цілому. Робота з математичною моделлю процесу і обчислювальний експеримент дають можливість безболісно, відносно швидко і без істотних витрат досліджувати властивості і поведінку процесу в різних ситуаціях. 